\title{
Evolution of the Conditions for Successful Innovation in Remote Networked Schools
}

\author{
Christine Hamel $^{1}$, Sandrine Turcotte ${ }^{2} \&$ Thérèse Laferrière $^{1}$ \\ ${ }^{1}$ Faculty of Education, Université Laval, Québec, Canada \\ ${ }^{2}$ Faculty of Education, Université du Québec en Outaouais, Gatineau, Canada \\ Correspondence: Christine Hamel, Faculty of Education, Université Laval, QC, G1V 0A6, Canada. E-mail: \\ christine.hamel@fse.ulaval.ca
}

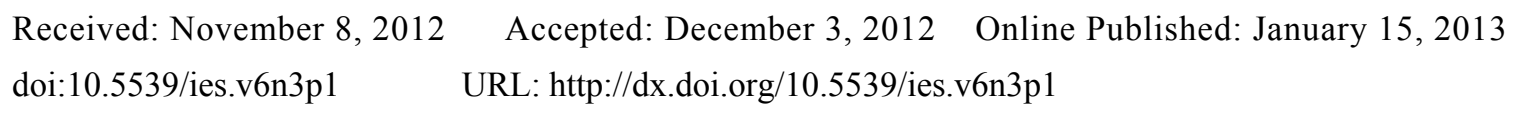

The research is financed by CEFRIO

\begin{abstract}
This paper investigates the presence (or absence) of Ely's (1999) conditions for implementing innovation in a rural context in the province of Quebec (Canada). The innovation, namely the Remote Networked School (RNS) initiative, is designed to bring new technology tools to enrich the learning environment of students and diminish teachers' isolation in the smallest and most remote schools of the province. The study presents a discourse analysis of four major stakeholder groups of the RNS initiative over three years. The qualitative analysis was designed to identify: 1) the conditions for innovation that were most present in stakeholder discourse over the years; 2) the indicators that strengthened the conditions for innovation presence or absence; and finally, 3) certain variations occurring during the adoption/implementation years of the RNS initiative. This paper reconfirms the adequacy of Ely's model as an effective framework for understanding and monitoring ICT-based systemic teaching and learning innovations such as the province-wide RNS initiative in Quebec.
\end{abstract}

Keywords: innovation, conditions, indicators, implementation, rural schools, professional development

\section{Introduction}

Educational systems are continually called upon to redefine themselves in order to meet the needs of societies. Hence, the past decade has seen a number of significant school reforms so that they can better meet society's need for knowledge (Drucker, 1999). These reforms seek to improve the school's performance and thus allow more students to succeed, ensuring them a better future. What happens when these schools are situated in rural areas, where few teaching resources are available? Rural schools are important to ensure the vitality of their communities, they form their heart. In the province of Quebec, Canada, such schools represent nearly $40 \%$ of all schools and, on average, have fewer than 100 students at the elementary level. During the most recent curriculum reform (MELS, 2001), the government of Quebec highlighted the great importance of ensuring equality of success in education for all Quebec students. How can equal success be ensured when some regions have not a lot of educational resources available? In response to significant questioning at the Estates General on Education (MEQ, 1997), the Initiative École éloignée en réseau (the remote networked schools initiative) was born. It was designed to enrich the learning environment in rural schools by using collaborative technologies in the classroom. This article seeks to explain what conditions for innovation (Ely, 1999) were implemented in participating school boards over a period of five years to ensure successful innovation from the standpoint of the participating stakeholders, i.e., the teachers, management, academic advisors, and superintendants. The goal of this paper is to understand and analyze the process to support the implementation of innovation as revealed by the comments of its principal stakeholders.

\subsection{Conceptual Background}

\subsubsection{Innovating to Transform the Learning Environment in a Rural Setting}

The curriculum reform implemented in Quebec, as elsewhere in the world, involved transforming teaching practices with study programs now being defined by a series of competencies to be developed in students. 
Adapting learning environments is demanding since stakeholders must all modify their practices to be consistent with this reform (Bransford, Brown, \& Cocking, 1999; Brannan-Ritland, 1999; Reigeluth, 1999). Design of the learning environment for the knowledge-based society must include a high potential for interaction for learning purposes among students, exceed simple stimuli and receive automated responses (Bransford et al., 2000; Lave \& Wenger, 1991). Consequently, the new study programs have been designed to offer more authentic learning opportunities anchored in the students' culture; the study programs are designed to focus on students' actions (MEQ, 2001).

In order to support students and teaching institutions, several training opportunities were offered to provide an understanding of the program reforms. Typically, teachers were placed in teams organized by grade-level to develop learning activities consistent with the program in their schools (Barma, 2008). But what happens when teachers in small rural schools are isolated within their school because they teach three different levels? In Quebec, as in the rest of Canada, teachers and learners in small rural schools face several challenges due to the vastness of the territory served by the school as well as out-migration to cities. These schools, which have fewer than 100 students each, face declining demographics. They lack the capacity to provide adequate services to the community and are sometimes forced to close because of insufficient numbers. Others schools remain open but have very low student enrolment, sometimes only one student per grade. Such situations considerably reduce peer interactions between same-age students. Furthermore, teachers report that multi-grade classrooms imply heavy teaching loads (Author and colleagues, 2012). Hence, if you consider that learning is a social and cultural act, and that it is essential for all students to be able to succeed, how does one ensure that everyone is able to access quality interactions, including students attending very small schools.

\subsubsection{Innovating with Technologies within a School Context}

ICTs, e-learning and innovation are often considered by government and researchers as effective solutions for providing equal opportunities for instruction and success in schools everywhere (Barbour, 2010; Canadian Council of Learning, 2009; Conseil Supérieur de l'Éducation, 2009). Rogers (2003) defines innovation as an idea, practice or object that is perceived as new by an individual. Diffusion is the process by which an innovation is communicated through certain channels among members of a social system over time. Individuals can reject or accept the innovation in their practice and make decisions about it during the process. The main challenge in diffusing innovation is its sustainability in the system (Rogers, 2003; Cuban, 2010).

Innovation or change in schools or educational systems is not a new field of study nor is it a new practice (Banathy, 1991; Berman \& McLaughlin, 1978; Blumenfeld, Fischman, Kracjick \& Marx, 2000; Ely, 1999; Fishman, 2000; Fullan, 2001; Spillane, Reiser \& Reiner, 2002). However, societal barriers are tenacious. They include a reluctance to use technologies to innovate in schools (Becker \& Riel, 2000; Cuban, 1986; Morehouse \& Stockdill, 1992; Plante \& Beattie, 2004; Zhao, Pugh, Sheldon, Byers, 2002) and the main obstacles of the integration of educational technologies in schools (Becker \& Riel, 2000; Kozma, 2003; Author, 2005). Analytical frameworks exist that explain the innovation process, including Rogers' Innovation-Decision-Process Model (2003), Hall and Hord's Concerns Based Adoption Model (CBAM) (1987, 2001) and Blumenfeld and colleagues' (2000) diagnostic model for systemic innovation. Several challenges to innovation with ICT use remain at the systemic level (e.g., stakeholders' decision-making processes regarding adoption beyond the classroom level and throughout the system; Author, 2011; Blumenfeld et al., 2000; Reigeluth, Carr-Chellman, Beabout \& Watson, 2007).

One common way to respond to the need for change and innovation in education is through the introduction of information and communication technology in classrooms, often by adding a new technological tool rather than providing orientation and time for teachers to change their practices. Consequently, the expected changes rarely occur or are rarely sustainable (Cuban, 2010; Christensen, Johnson \& Horn, 2008; Seidel \& Perez, 1994). They do not really transform students' learning environment in ways leading to deeper understanding or knowledge creation. Teachers that embark on such a path are often alone and sustainability becomes a challenge. Therefore, deep educational innovation remains a major challenge for our schools and our society (Bereiter, 2002; Christensen, Johnson \& Horn, 2008; Cuban, 2010; UNESCO, 2008).

Our assumption is that a better understanding of the conditions for innovation that apply to a whole educational system can lead to more successful diffusion of innovation and make it more sustainable. Innovative models focussed primarily on change agents or a specific technology rarely succeed in a complex system (Cuban, 2010; Ellswoth, 2000; Rogers, 2003). Thus, centeredness on the individual as an agent of change or on specific technological tools for change depart from the processes already in place to support innovators in an educational system. 
For this reason, Ely's framework of baseline conditions that facilitate innovation is relevant to understanding the innovative process in a system (Ely, 1990, 1999; Esminger, Surry, Porter, \& Wright, 2004).

The following are Ely's conditions for innovation:

- Dissatisfaction with the status quo: One of the first steps to initiate change in an education environment is a sense of dissatisfaction with current conditions.

- Knowledge and skills: People who are willing to implement any type of innovation must possess sufficient knowledge and skills in order for the change to occur.

- Available resources: The amount of resources that must be available to successfully implement the innovation. Resources include finances, hardware, software and personnel.

- Available time: Implementers must have time to learn, adapt and reflect on what they are doing.

- Rewards or incentives for participants: There must be incentives and rewards to motivate users to implement the innovation.

- Participation is expected and encouraged: Each stakeholder needs to be included in the planning and decision-making process for implementation at each level.

- Commitment: There must be firm and visible evidence that the organization actively supports the implementation of the innovation.

- Leadership must be conspicuous: The leader should be clearly identified, at both the organization and project levels, because innovators need inspiration and support to implement change/innovation.

Ely's conditions for innovation are rather well defined and mutually complementary but may take different meanings and shapes as the implementation of an innovation progresses. In a particular context, yesterday's most critical conditions may no longer meet today's specific needs. Therefore, one has to apprehend this framework as flexible and evolutionary. The context of our study allowed us to trace how Ely's conditions for innovation applied throughout the implementation of a systemic innovation in Quebec. Too often, innovations are brought into the school system without any real measure of success and are often abandoned once support measures are withdrawn (Cuban, 2010). It is within this context that we implemented the Remote Networked School (RNS) design to monitor the evolution of implementing conditions for innovation in a systemic context.

\subsubsection{A Context for Innovation: Small Rural Schools in the Midst of a Demographic Shift}

Over the last ten years, in order to address problems associated with demographic decline, almost $15 \%$ of Quebec's small rural schools have been participating in a design experiment called the Remote Networked School, funded by the Quebec Ministry of Education, Leisure and Sport (MELS) and focused on enriching the learning environment. Quebec has a commitment almost as "big as the size of its territory", to equality of opportunity and it wants to keep its capacity to apply this principle as well as its capacity to occupy its territory. The RNS initiative was first launched in three school districts (2002, Phase I), and then extended to ten additional school districts in 2004 (Phase II and III). After its third phase, with 22 participating school districts, the initiative is now in its fifth phase, for a total of 24 participating school districts, i.e., one-third of all Quebec school districts.

This innovation design included the use of ICTs. Teachers planned learning activities by regular videoconference, but also met face-to-face occasionally during the school year. Some teachers worked together on planning throughout the school year and implemented learning activities using these technologies while others partnered for specific activities, using these technologies as a support for collaboration among themselves and among the students. A leader from each school district, usually the district pedagogical consultant, was assigned to support the local team of teachers and principals and to interact with the research team and the MELS. Furthermore, a member of the university-based research and intervention team was also available online throughout the day via a desktop videoconferencing system in order to help local stakeholders plan educational activities, resolve technical problems, offer various types of support, and respond to rising needs (known as just-in-time professional development) (Authors, in press).

To address the systemic complexity of the innovation, each school district assigned a coordinator for the initiative and a minimum of one pilot school was paired with partner schools in other districts in order to allow for collaboration and interaction between classrooms. Two technological tools were chosen to support interaction, learning and knowledge building between schools. The first was a desktop videoconferencing system (iVisit), the second was Knowledge Forum (KF), a collaborative writing space specially designed for knowledge building (Scardamalia \& Bereiter, 2006). The students and teachers used the two tools collaboratively to work on 
authentic problems, mainly in science and social sciences. Phase I resulted in an increase in student interaction in the classroom and in student-centered activities (Author and colleagues, 2004). Moreover, the teachers noticed that their students were more motivated while working in class with peers in distant classrooms and with the experts they contacted through the videoconference system. In Phase II, more than 40 classes worked with well-known authors, meeting them through videoconference and building knowledge about writing and creativity in KF. In Phase III, some projects included understanding climate change through collaboration between classrooms in Quebec, Hong Kong and Barcelona.

The RNS represents a systemic innovation marked by issues likely to impinge on the success of its implementation in other school districts. Such issues included the management of human resources (e.g., large turnover of the teaching staff in small rural schools), school organization (e.g., the constraints of tele-collaboration such as conflicting schedules in different schools), access to quality user-friendly equipment, and teachers' beliefs regarding the planning of networked learning and knowledge-building activities. Multi-grade classrooms, teachers' lack of experience, principals having several schools to manage, and the learning curve regarding the use of ICTs are all issues part of the context in which the innovation takes place. Given the complexity of the innovation, what conditions for innovation were put in place for the adoption/diffusion of the RNS model by remote schools?

\section{Method}

To study the conditions for innovation present in the RNS context, we analyzed stakeholder discourse over a three-year period (2004-2007). This paper addresses three research questions:

1) Which conditions for innovation were most frequent in stakeholder discourse when describing their successes, difficulties and goals for the RNS?

2) Which indicators of the conditions for innovation did stakeholders mention most frequently?

3 ) Is there an observable effect in the evolution of the conditions for innovation across years of implementation?

The RNS initiative takes the form of a design experiment (Brown, 1992; Collins, 1992, 1999; Design-based Research Collective, 2003), a methodology specifically focused on educational innovation. One characteristic of design experiment research (Collins, Joseph, \& Bielaczyc, 2004) is its iterative process: participants are informed, through data collection, of a question pertaining to common interests. Then, additional questions and steps for better understanding and improving practices are identified. In the RNS initiative, stakeholders were involved in the iterative process, thus making the process of innovation, transparent, accountable at all levels and based on practitioners' concerns. In the RNS design, Ely's (1999) framework, with his conditions for facilitating innovation, was an obvious choice because it was drawn from theories pertaining to innovation, and because the focus was not on the difficulties particular to the innovation process but rather on what could enable it. Consequently, we relied on this framework to provide baseline data for the launching of the RNS in 2002. Moreover, Ely's conditions for innovation were clearly defined and easy for stakeholders to understand. Most of them found that Ely's conditions for innovation were coherent, well founded and useful in their work.

Ely's framework $(1990,1999)$, along with his eight conditions for innovation, were chosen to guide as well as understand the stakeholders' adoption and implementation of the RNS model. For example, in Phase I, each teacher received a laptop computer, which was considered a reward encouraging them to make a commitment to RNS (Author, and colleagues 2004). This element was seen as key by the school districts joining later (Phase II), which also provided laptops to most of their participants. Teachers who did not receive a laptop showed less commitment or felt less recognized by their school district (Authors, 2008).

\subsection{Analysis Grid}

Ely's eight conditions were adapted to fit the RNS even more closely. This is also consistent with Ely's approach (1999). The adaptation process was based on the results of the Phase I report (Author, and colleagues, 2004) and on field observations made within each of the new school districts that joined RNS in 2004. The eight conditions were also defined more explicitly to help stakeholders understand their specifics and the implications of their participation in the RNS initiative. Indicators were developed in conjunction with the stakeholders (school board pedagogical consultants, school principals, teachers, school district pedagogical consultants) and concrete manifestations of the presence of the eight conditions were identified. Table 1 details the indicators identified for each condition of innovation. 
Table 1. Conditions for innovation and observable indicators

\begin{tabular}{|c|c|}
\hline Conditions for innovation & Indicators \\
\hline Dissatisfaction with the status quo & $\begin{array}{ll}\text { - } & \text { Professional isolation } \\
\text { - } & \text { Lack of same-age student peer interaction } \\
\text { - } & \text { Lack of general awareness } \\
\text { - } & \text { Students' lack of motivation } \\
\text { - } & \text { Students' poor performance } \\
\text { - } & \text { Limited range of education (e.g., few elective courses) } \\
\text { - } & \text { Frequent turnover of personnel } \\
\text { - } & \text { Limited access to specialized resources } \\
\text { - } & \text { Lack of diversity in learning activities }\end{array}$ \\
\hline Knowledge and skills & $\begin{array}{ll}\text { - } & \text { Local teacher leadership } \\
\text { - } & \text { Socio-constructivist discourse } \\
\text { - } & \text { Open-ended curriculum applied locally } \\
\text { - } & \text { Discourse about learning and ICTs } \\
\text { - } & \text { Daily use of email and Web browser } \\
\text { - } & \text { Knowledge and skills with the two tools (iVisit and KF) } \\
\text { - } & \text { Effective integration of RNS in practice }\end{array}$ \\
\hline Available resources & $\begin{array}{ll}\text { - } & \text { Just-in-time pedagogical support } \\
\text { - } & \text { Professional development activities on demand } \\
\text { - } & \text { Just-in-time technical support } \\
\text { - } & \text { Large bandwidth } \\
\text { - } & \text { Support from all the stakeholders } \\
\text { - } & \text { Support from the local community } \\
\text { - } & \text { Easy and quality access to software and hardware } \\
\text { - } & \text { Technical difficulties kept to a minimum } \\
\text { - } & \text { Support and challenge from the research team } \\
\text { - } & \text { Partner classrooms for collaborative work }\end{array}$ \\
\hline Time & 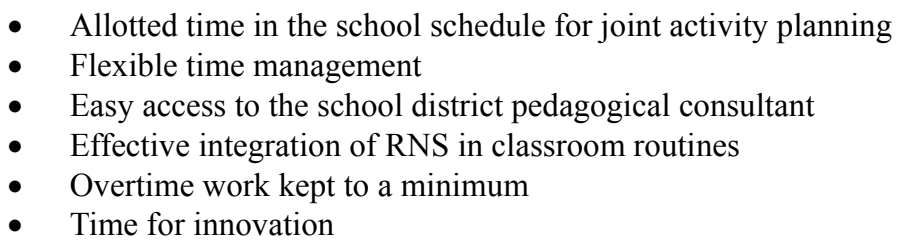 \\
\hline Participation & $\begin{array}{l}\text { - } \quad \text { Shared leadership among the stakeholders } \\
\text { - } \quad \text { Teachers' ideas and needs considered }\end{array}$ \\
\hline Rewards or incentives for the participants & $\begin{array}{l}\text { - } \quad \text { Laptop given to each participating teacher } \\
\text { - } \quad \text { RNS-related activities conducted during the school day } \\
\text { - } \quad \text { RNS included in school/school district strategic plan } \\
\text { - } \quad \text { Appreciation of accomplishments in public presentations } \\
\text { - } \quad \text { Local recognition of the network culture } \\
\text { - } \quad \text { Other forms of rewards }\end{array}$ \\
\hline Commitment & $\begin{array}{l}\text { - } \text { Financial commitment of the school district } \\
\text { - } \\
\text { - } \\
\text { - } \\
\text { - }\end{array}$ \\
\hline Leadership & $\begin{array}{l}\text { - } \quad \text { Presence of at least one teacher leader } \\
\text { - } \quad \text { Interaction between teacher leader(s) and the research team } \\
\text { - } \quad \text { Principals who guide, support and encourage their local team } \\
\text { - } \quad \text { Teachers' easy access to teacher leaders } \\
\text { - } \quad \text { Principals participating in their RNS community of practice }\end{array}$ \\
\hline
\end{tabular}

\subsection{Data Collection}

An online questionnaire, administered at the end of the school year in 2005, 2006 and 2007, was submitted to the four different types of RNS stakeholders: 1) teachers, 2) school principals, 3) school board pedagogical consultants, and 4) RECIT (ICT consultants). The questionnaire contained 49 to 71 questions (depending on the 
type of stakeholder and the year of the administration of the questionnaire) with multiple-choice answers (5-item Likert scale), as well as open-ended questions.

This paper reports the results regarding the open-ended questions, thus complementing the previously published quantitative results and providing new highlights (Turcotte \& Hamel, 2008). At the end of 2005, two additional open-ended questions were asked of the stakeholders:

1) RNS is a success in my environment because...

2) For RNS to be successful in my professional life, in the next 16 months I would like to achieve the following...

In the two subsequent years $(2006,2007)$ there were three open-ended questions:

1) The signs of success of RNS in my environment are...

2) The implementation of RNS was more difficult in my context because...

3) RNS was successful in my professional life because...

The first step in analysis of the stakeholders' written discourse was identifying units of analysis of a thematic nature. As such, every time a different idea was identified in the discourse, an appropriate code was attributed (Hayes \& Krippendorff, 2007; Krippendorff, 2003). Therefore, the unit of analysis related to meaning rather than structure (sentence). For example, a teacher gave the following answer:

"This project allows me to enrich my teaching practice, to break isolation, and to develop my ICT skills. The software helped me better understand some learning activities."

The answer was split into thematic units of analysis as follows:

"This project allows me to enrich my teaching practice

[This project allows me] to break isolation

[This project allows me] to develop my ICT skills

The software helped me better understand some learning activities."

Punctuation was usually an indication of a potential new idea, like the commas in the preceding example. However, this was not always the case, so meaning was always the decisive element. The units of analysis are independent of each other (see Table 1). Coding was done by three different coders, with inter-rater agreement (91 \%) (Miles \& Huberman, 1999). Statistical analyses were then conducted to see the effects of interactions between conditions for innovation (two-tailed chi-square analysis).

Table 2 details the number of answers with respect to each type of stakeholder. From all the answers that were analyzed, $15.24 \%$ of the thematic units (298) were withdrawn from the data because they did not relate to any of the conditions for innovation.

Table 2. Number of answers and occurrences in stakeholders' discourse

\begin{tabular}{lllllll}
\hline Year & Number of answers & & & \multicolumn{2}{c}{$\begin{array}{l}\text { Number of } \\
\text { occurrences }\end{array}$} \\
\hline & Teachers & Principals & $\begin{array}{l}\text { Pedagogical } \\
\text { consultants }\end{array}$ & RECIT & Total \\
& & & & & & \\
$\mathbf{2 0 0 4 - 2 0 0 5}$ & 118 & 32 & 19 & 13 & 182 & 552 \\
$\mathbf{2 0 0 5 - 2 0 0 6}$ & 75 & 24 & 8 & 9 & 116 & 700 \\
$\mathbf{2 0 0 6 - 2 0 0 7}$ & 60 & 24 & 8 & 5 & 97 & 404 \\
\hline
\end{tabular}

\section{Results}

\subsection{The Importance of Each Condition for Innovation in Stakeholder Discourse}

Three prevailing conditions were identified in stakeholder discourse, and this was true across the three years of implementation: dissatisfaction with the status quo, knowledge and skills, and available resources. Altogether, these conditions accounted for nearly $75 \%$ of the conditions for innovation identified in the answers given by the 
stakeholders in response to the open-ended questions (see Figure 1). The most frequently mentioned condition was knowledge and skills, with 433 occurrences, followed by dissatisfaction with the status quo (411), and available resources (393). Given that RNS innovation is demanding on a pedagogical level when implemented it in class (knowledge building), it is not surprising to see that this is a predominant condition in the discourse. What 's more, this allows us to understand the innovation requirement in participants' practice so that they can succeed in integrating it.

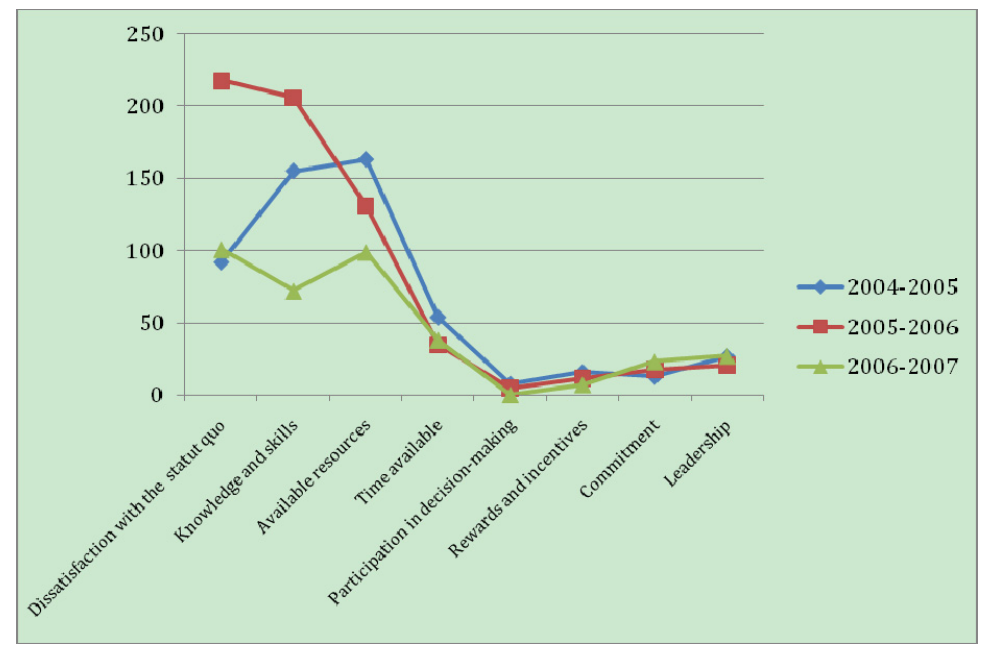

Figure 1. Distribution of the conditions for innovation identified in stakeholders discourse across time

As explained in the methodology, occurrences do not refer to the presence of the conditions for innovation in the context, but rather to the presence of their indicators in stakeholder discourse. That being said, Figure 2 shows whether the conditions for innovation mentioned in the discourse of stakeholders were considered as present or absent in their context. Dissatisfaction with the status quo, knowledge and skills generally appeared as present as opposed to resources and available time, which were more often mentioned as being absent.

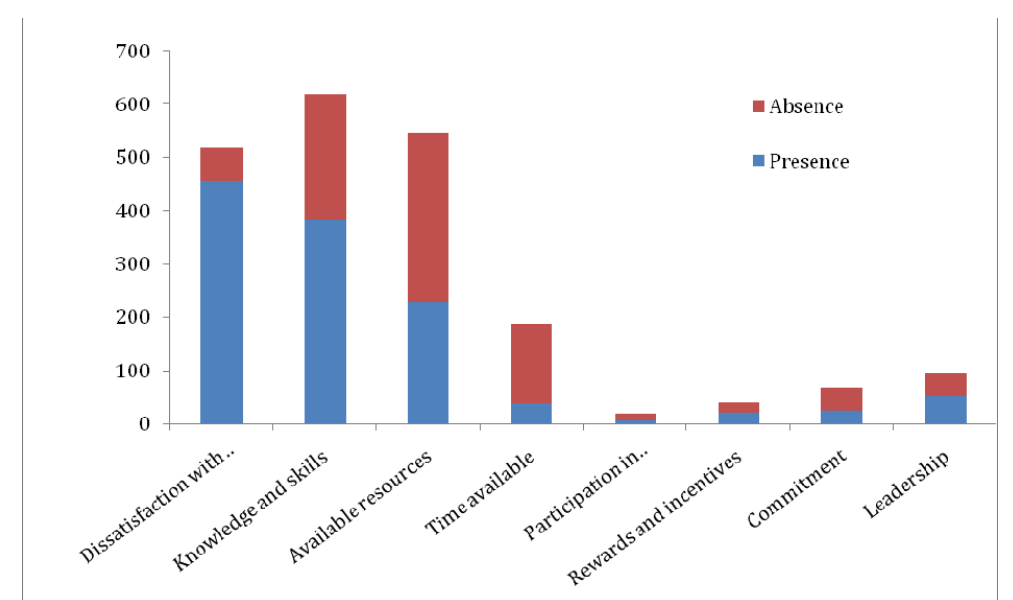

Figure 2. Distribution of presence and absence of conditions for innovation in the discourse of stakeholders

\subsection{Specific Indicators of Conditions for Innovation Present in the Discourse}

In 2004-2005, the three most frequent indicators for all the conditions were: effective integration of RNS in practice (94), professional isolation (48), and knowledge and skills with the two tools (iVisit and KF) (42). In 2005-2006, the first indicator was the students' lack of motivation (84), followed by professional isolation (63), and knowledge and skills with the two tools (58). In 2006-2007, the three most frequent indicators mentioned were professional isolation (38), technical difficulties (32), and knowledge and skills with the two tools (27). This data is illustrated in Table 3, along with the percentages for each element across years. 
Table 3. Three most frequent indicators cited in stakeholders' discourse for each year of implementation

\begin{tabular}{|c|c|c|c|c|c|c|c|c|}
\hline 2004-2005 & & & 2005-2006 & & & 2006-2007 & & \\
\hline $\begin{array}{l}\text { Effective } \\
\text { integration of } \\
\text { RNS in practice }\end{array}$ & 94 & $17.00 \%$ & $\begin{array}{l}\text { Students' lack of } \\
\text { motivation }\end{array}$ & 84 & $12.00 \%$ & $\begin{array}{l}\text { Professional } \\
\text { isolation }\end{array}$ & 38 & $9.41 \%$ \\
\hline $\begin{array}{l}\text { Professional } \\
\text { isolation }\end{array}$ & 49 & $8.86 \%$ & $\begin{array}{l}\text { Professional } \\
\text { isolation }\end{array}$ & 63 & $9.00 \%$ & $\begin{array}{l}\text { Technical } \\
\text { difficulties }\end{array}$ & 32 & $7.92 \%$ \\
\hline $\begin{array}{l}\text { Knowledge and } \\
\text { skills with the } \\
\text { two tools }\end{array}$ & 42 & $7.59 \%$ & $\begin{array}{l}\text { Knowledge and } \\
\text { skills with the } \\
\text { two tools }\end{array}$ & 58 & $8.29 \%$ & $\begin{array}{l}\text { Knowledge and } \\
\text { skills with the } \\
\text { two tools }\end{array}$ & 27 & $6.68 \%$ \\
\hline
\end{tabular}

Just as in the preceding results, the pedagogical requirement for innovation reflects participant discourse. Thus, in the first year, the participants mentioned the importance and difficulty of integrating the RNS into their current practice, as well as their professional isolation and their lack of knowledge about the technological tools. Moreover, each year this indicator takes up a lot of space in the discourse. It is the same for the professional isolation of teachers in small schools, which is predominant in the discourse. The RNS implementation years also served as the implementation years for significant curriculum reform, which had a great impact on teaching practices. Hence, participating in the RNS allowed teachers to reduce their professional isolation. Finally, it is surprising to see technical difficulties arise in the third year of research, which was the third year of RNS implementation.

\subsection{Evolution of the Conditions for Innovation According to Year of Implementation}

As shown in Table 3, indicators of the conditions for innovation identified in the discourse of the RNS stakeholders varied each year. Does this accurately reflect a change in the conditions for innovation as perceived by teachers, pedagogical consultants and principals? Figure 3 shows the evolution of each condition of innovation throughout the three years of implementation.

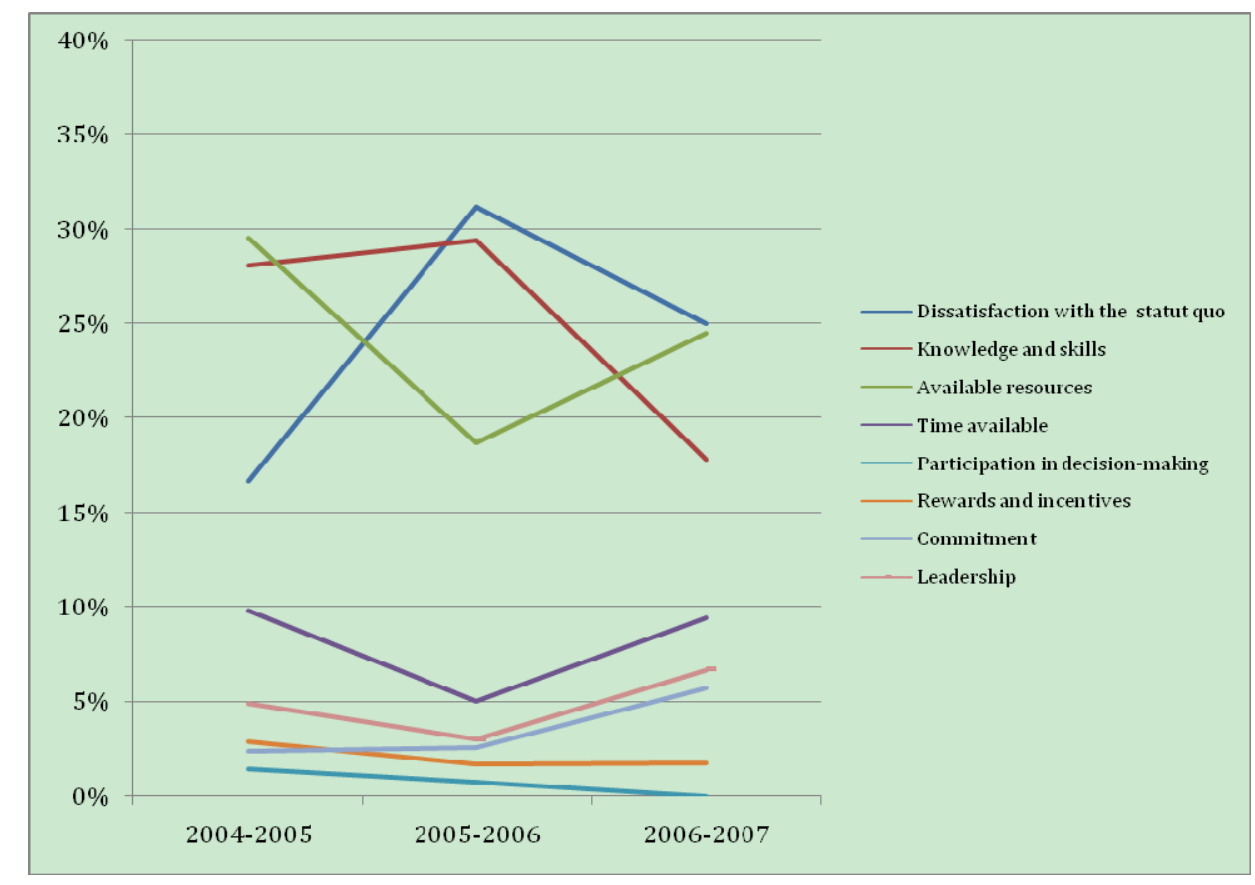

Figure 3. Evolution of the conditions for innovation in stakeholder discourse throughout the three-year implementation of RNS 
As shown in Figure 3, variations were observed:

- Dissatisfaction with the status quo increased over the second year of implementation. Likely, there was a clearer need for change as the RNS initiation proceeded and as stakeholders' experience grew.

- The knowledge and skills required in RNS were still high in the second year, but decreased in the third year.

- There was greater variation across implementation phases regarding available resources. During the first year of each phase (Phase II in 2004-2005 and Phase III in 2006-2007), resources seemed more important to the stakeholders. In the second year this condition declined, probably because the stakeholders had made the resources more easily available. For example, a majority of the RNS schools did not have broadband access in 2004-2005, but did a year later.

As mentioned earlier, a first discourse analysis generated occurrences of the indicators for each condition for innovation, whether conditions were perceived as being present or not in the context. When we later analyzed the occurrences, we were able to determine whether the conditions discussed were mentioned as being absent or not in the implementation context. The next results (Table 4) indicate which conditions were present or absent for the stakeholders, as reported in their written discourse.

Table 4. Presence or absence of the conditions for innovation in stakeholder discourse

\begin{tabular}{|c|c|c|c|c|c|c|}
\hline & \multicolumn{2}{|c|}{ 2004-2005 } & \multicolumn{2}{|c|}{ 2005-2006 } & \multicolumn{2}{|c|}{ 2006-2007 } \\
\hline & $\begin{array}{l}\text { Presence } \\
(\%)\end{array}$ & $\begin{array}{l}\text { Absence } \\
(\%)\end{array}$ & $\begin{array}{l}\text { Presence } \\
(\%)\end{array}$ & $\begin{array}{l}\text { Absence } \\
(\%)\end{array}$ & $\begin{array}{l}\text { Presence } \\
(\%)\end{array}$ & $\begin{array}{l}\text { Absence } \\
(\%)\end{array}$ \\
\hline Dissatisfaction with the status quo & 98.91 & 1.09 & 95.87 & 4.13 & 97.03 & 2.97 \\
\hline Knowledge and skills & 13.55 & 84.52 & 86.41 & 13.59 & 88.89 & 11.11 \\
\hline Available resources & 22.70 & 72.39 & 35.88 & 63.36 & 52.53 & 47.47 \\
\hline Time & 5.56 & 90.74 & 11.43 & 88.57 & 44.74 & 55.26 \\
\hline Participation & 25.00 & 75.00 & 40.00 & 60.00 & 0.00 & 0.00 \\
\hline Rewards or incentives & 6.25 & 81.25 & 75.00 & 25.00 & 85.71 & 14.29 \\
\hline Commitment & 23.08 & 76.92 & 33.33 & 66.67 & 47.83 & 52.17 \\
\hline Leadership & 40.74 & 59.26 & 52.38 & 47.62 & 55.56 & 44.44 \\
\hline
\end{tabular}

Dissatisfaction with the status quo was the condition for innovation most frequently mentioned in stakeholder discourse, and this occurrence was characterized by a high presence of the condition in the context. When stakeholders mentioned anything relating to this condition, it was because they had certain concerns regarding the current situation: isolation, students' lack of motivation, need for interaction, etc. Hence, the RNS tools and the new practices that these tools enabled improved their satisfaction level (Authors and colleagues, 2009).

Knowledge and skills varied significantly throughout the years of implementation; from being mostly absent in 2004-2005, this condition became present in 2005-2006 and in 2006-2007. We believe this variation was due to one particular indicator, the Effective integration of RNS in practice, which in 2004-2005 was identified in the discourse of stakeholders as being mostly absent. This shows that RNS was not effectively implemented in the first year. In our opinion, it was somewhat normal that stakeholders did not feel that they had succeeded in integrating RNS effectively in their practices during the first year because it represented an important challenge for them. It was quite interesting to see, however, that after their first year, stakeholders stated that they had the knowledge and skills needed to implement RNS in their practice.

Resources became increasingly present as the initiative progressed. However, even though this condition was mentioned less often at the end of 2005-2006 and 2006-2007 compared to the first year, availability of resources remained a concern nevertheless. A similar effect could be observed with the presence of the time condition. Indeed, it was our perception that, initially, the time arrangements allotted to help the innovative process among the stakeholders was less effective. However, as the initiative developed, new time arrangements that were more 
coherent and better adapted to the practice of the stakeholders were made. For example, teachers could opt to be relieved of their teaching task for two hours every two weeks for planning sessions with their distant colleagues. These new time arrangements were especially beneficial for teachers with less flexible schedules because they provided opportunities for professional development. It became clear that this condition for innovation helped generate favourable results, even if the availability of time remained a challenge in subsequent years.

Furthermore, teachers' participation evolved in a positive way: the number of occurrences became increasingly present in their discourse as more teachers engaged in the initiative. We believe their participation in the decision-making process improved because this condition evolved from being a condition considered as absent in their individual contexts to a condition not even mentioned in the third year. This change may have been related to the evolution of the condition of knowledge and skills-as the stakeholders became more competent, they may have felt more committed to the RNS initiative and had more opportunities to participate in decision-making. Moreover, because the initiative was oriented toward knowledge building, it valued the use of technological tools in a creative manner (accommodation vs. assimilation, Seidel \& Perez, 1994). As a result, the new practices introduced were sometimes different from the stakeholders' practices observed at the very beginning of the initiative.

\section{Discussion}

The results of this analysis of open-ended questions build on and refine those of a previous study, which was based on close-ended questions (Authors, 2008). Indeed, stakeholders' reports on the presence of the conditions for innovation evolved over the three-year period. We submit that the following two themes are critically important for an innovative process to trigger a positive domino effect: 1) continuity and relevance of professional development, and 2) the reaching of a tipping point toward widespread adoption.

\subsection{Continuity and Relevance of Professional Development}

Working in small schools often means that teachers and other professionals feel alone and do not have many opportunities to collaborate with other colleagues. For example, the professional isolation indicator, which was predominant in the first year, became less present in the second year and was present again in the third year, even though some of the same teachers responded to the questionnaire each year. It appears that some stakeholders became more isolated in the third year because their practices were more advanced than those of their local colleagues and, thus, the former needed new partnerships to overcome their professional isolation once again. Throughout the three-year period, teachers often pointed to weaknesses regarding the use of technologies (CI: Knowledge and skills, Indicator: Knowledge and skills with the two tools). This supports the idea that, in a context of innovation, professional development is needed throughout the process and not only at the initial stage. (Christensen, Johnson \& Horn, 2008; Ely, 1999; Hall \& Hord, 2001; Rogers, 2003).

Moreover, the RNS design calls for the use of ICTs in ways to renew, and not simply reproduce, one's classroom practices (see the notions of assimilation and accommodation, Seidel \& Perez, 1994). It is uncertain whether decision-makers were aware of all efforts required from the teachers in order to effectively use these new tools to enrich their learning environment (Christensen, Johnson \& Horn, 2008; Cuban, 2010; Fullan, 2001; Rogers, 2003). "Just-in-time" distance professional development was offered and was in-demand, which indicates that learning to use the technological tools and knowledge building was an incremental process that required more than a yearly teacher training session on a specific tool. As recommended by Blumenfeld and colleagues (2000), such professional development was adapted to the actual practice and experience of the stakeholders, and considerable progress was achieved (Authors, 2011).

Furthermore, the recognition of the competencies of the stakeholders with more experience, especially teachers, can become a potential trigger for a domino effect (Ely, 1999; Rogers, 2003; Cuban, 2010). However, this does not mean that leadership by principals should be "delegated" to teachers. If this occurs, the adoption/implementation process may be delayed, especially when the innovation is not embraced by the professional learning community (Dufour, 2004) and remains only at the classroom level (Fullan, 2001; Cuban, 1986, 2010). The weak presence of leaders' commitment and leadership conditions clearly shows that there is still work to be done to secure innovation on a systemic level.

\subsection{Reaching the Tipping Point}

The tipping point is crucial in a changing process because it implies that the innovation is being integrated into the social system by bringing new and irreversible development, as would occur with a domino effect (Rogers, 2003). It would be most desirable for the RNS initiative to reach such a tipping point, considering the challenges that small rural schools still face in the province of Quebec. This is very difficult to achieve, however, because at 
the beginning of each school year, decision makers have to reconsider certain elements pertaining to conditions for innovation (Author, 2011). For example, the fact that time and available resources were conditions almost never present in stakeholders' discourse is worrisome. Combined with significant personnel turnover in the school districts and the schools, our results point to the fragility of RNS innovation over time.

In our previous paper, (Authors, 2008), stakeholders did not perceive time to be as important as the other conditions. However, teachers had mentioned to the research team the lack of time for integrating the two tools in their practice, and their responses to the open-ended questions of the questionnaire indicated a need for additional time to innovate and implement practice. Was this the result of self-imposed constraints in their regular class schedule, or were other elements at play? More inquiry is needed regarding which time arrangements facilitate (or hinder) the understanding and implementation of innovation (see also the results of Esminger et al., 2004). The notion of time differs for each stakeholder and consolidating the RNS in the participants' routines should allow for this condition to become less significant over the long term.

As for resources, they must be made available throughout the years, and respond adequately to stakeholders' needs in order to be a factor in triggering the domino effect (Blumenfeld et al., 2000; Ely, 1999; Rogers, 2003). Over time, resources tended to diminish: in the third year, which corresponded to the first year of a new RNS phase (Phase IV), it appeared fewer resources were available. In some classrooms, computers were not present at the beginning of the school year. This variability in the availability of resources may have been the result of a delay in budget renewal for each school district. Furthermore, ensuring continuity of resources is a strong expression of decision makers' commitment to implementing an innovation (Cuban, 2010, Fullan, 2001; Author, 2011). However, the addition of new teachers engaged in the RNS in 2006-2007 may have impacted the availability of resources and the knowledge and skills conditions in stakeholders discourse. Additionally, the use of technological tools contributed to an increasing need for professional development (Blumenfeld et al. 2000; Christensen, Johnson \& Horn, 2008; Fullan, 2001).

Implementation of the RNS initiative has been underway for several years. However, it has not yet reached the tipping point. A good indicator of its sustainability will likely be the planning of the resources to be allocated in the coming years. Moreover, the RNS will have to cease being perceived as an initiative, and become an integral part of stakeholders' practice.

The results presented and discussed in this paper provide additional empirical data and knowledge, which further support the understanding of an innovative educational context such as the Remote Network School initiative in Quebec (Canada).

First, this study has shown that Ely's conditions to facilitate the implementation of educational technology innovations $(1990 ; 1999)$ remain highly relevant in order for deep innovation to occur in classroom practice and at the school district level. Hence, as is the case here, such innovation can unfold over several years, during which some of the conditions can be absent from (or present in) discourse when stakeholders reflect on their innovation process. Indeed, some conditions may be completely absent from the discourse at first, but be present a year later, and then disappear again in the following year, or vice versa. While it would seem that the alternation between being absent and present indicates that a given situation was resolved, this was not the case here. For example, one clear indicator of dissatisfaction with the status quo, professional isolation, was mentioned by teachers in the first year of RNS, then was considered resolved in the second year as fruitful partnerships developed. However, this did not prevent the same teachers from experiencing professional isolation during their third year in RNS, resulting in the reappearance of this indicator in their discourse.

Similarly, although we did anticipate some conditions to disappear from the discourse (e.g. incentives such as having a laptop) because they had become part of the RNS routine, we also anticipated other conditions for innovation to be continuously present, such as the availability of resources.

We would like to emphasize that partnerships among professionals should not be taken for granted at the local level. Sufficient time and resources should be invested in supporting them and generating new partnerships to address the problem of professional isolation, which remained the most frequently mentioned indicator in the RNS stakeholders' discourse. This has a significant impact on classroom practice and we should not underestimate the consequences of the availability, or lack thereof, of resources and time needed to address this condition.

Schools and school district administrators may use the results of this study to better understand the accompaniment of an innovation process over a longer period. Indeed, too often, teachers and principals are asked to participate in small initiatives. We suggest this undermines the possibility for true transformation of the 
learning environment. Focusing only on trendsetting technology to bring about innovation can hardly result in a real transformation of the learning environment.

In addition, this study demonstrates that several changes occur during the implementation years of a complex innovation and it becomes difficult to identify a single possible solution to the various difficulties encountered. With these well-defined conditions, Ely enables us to track such changes and adapt our solutions. For example, we hope to see local stakeholders take over the "just-in-time" support and the professional development activities that have been provided so far by the intervention and research team. Such steps forward would be important indicators of the institutionalization of RNS practices at the local level.

In the years to come, we plan to revisit the indicators of the conditions for innovation in the same or in a different context. The following questions are of increasing importance: Are local professional development and collaborative pedagogy supported in progressive ways? What types of deployments of the RNS are observed at different sites? The study of patterns would enable further understanding of the innovation process while taking into account cultural and local contexts; this would be highly beneficial for practitioners and researchers alike.

\section{References}

Banathy, B. H. (1991). Systems design of education: A journey to create the future. Englewood Cliffs, NJ: Educational Technology Publications.

Bannan-Ritland, B. (1999). Teaching instructional design: An action learning framework. ITForum, 37.

Barbour, M. K. (2010). State of the nation study: K-12 online learning in Canada. Vienna, VA: International $\begin{array}{llllll}\text { Council for } & \text { K-12 Online } & \text { Learning. } & \text { Retrieved }\end{array}$ http://www.inacol.org/research/docs/iNACOL_CanadaStudy10-finalweb.pdf

Barma, S. (2008). Vers une lecture systémique du contexte, des enjeux et des contraintes du renouvellement des pratiques en éducation aux sciences au secondaire au Québec. Revue canadienne des jeunes chercheurs en éducation, 1(1).

Becker, H., \& Riel, M. (2000). Teacher professional engagement and constructivist-compatible computer use. Report \#7 Teaching, Learning and Computing: 1998: National Survey. Retrieved April 12, 2009, from http://www.crito.uci.edu/tlc/findings/report_7/startpage.html

Bereiter, C. (2002). Education and mind in the knowledge age. Mahwah, NJ: Lawrence Erlbaum Associates.

Berman, P., \& McLaughlin, M. (1978). Federal programs supporting educational change. Implementing and sustaining innovations, 8 . Santa Monica: Rand.

Blumenfeld, P. C., Fishman, B. J., Kracjik, J., \& Marx, R. W. (2000). Creating usable innovations in systemic reform: Scaling up technology-embedded project-based science in urban schools. Educational Psychologist, 35, 149-164. http://dx.doi.org/10.1207/S15326985EP3503_2

Bransford, J. D., Brown, A. L., \& Cocking, R. R. (1999). How people learn: Brain, mind, experience, and school. Washington, DC: National Academy Press.

Brown, A. L. (1992). Design experiments: Theoretical and methodological challenges in creating complex interventions in classroom settings. The Journal of the Learning Sciences, 2(2), 141-178. http://dx.doi.org/10.1207/s15327809j1s0202_2

Canadian Council of Learning. (2009). State of e-learning in Canada. Ottawa, ON: Author. Retrieved from http://www.ccl-cca.ca/pdfs/E-learning/E-Learning_Report_FINAL-E.PDF

Christensen, C. M., Johnson, C., \& Horn, M. (2008). Disrupting class: How disruptive innovation will change the way the world learns. New York: McGraw-Hill.

Collins, A. (1992). Toward a design science of education. In E. Scanlon \& T. O'Shea (Eds.), New directions in educational technology (pp. 15-22). New York, NY: Springler-Verlag. http://dx.doi.org/10.1007/978-3-642-77750-9_2

Collins, A. (1999). The changing infrastructure of education research. In E. Condliffe Lagemann, \& L. S. Shulman (Eds.), Issues in education research (pp. 289-198). San Francisco, CA: Jossey-Bass.

Collins, A., Joseph, D., \& Bielaczyc, K. (2004). Design research: Theoretical and methodological issues. Journal of the Learning Sciences, 13(1), 15-42. http://dx.doi.org/10.1207/s15327809j1s1301_2 
Conseil supérieur de l'éducation. (2009). L'éducation en région éloignée une responsabilité collective. Québec: Gouvernement $\quad \mathrm{du} \quad$ Québec. $\quad$ Retrieved http://www.cse.gouv.qc.ca/fichiers/documents/publications/CEBE/50-0188.pdf

Cuban, L. (1986). Teachers and machines: The classroom use of technology since 1920. New York: Teachers College Press.

Cuban, L. (2003). Why Is It So Hard To Get Good Schools? N.Y.: Teachers College Press.

Cuban, L. (2010). As Good as it Gets. Boston, MA: Harvard University Press.

Design-Based Research Collective. (2003). Design-based research: An emerging paradigm for educational inquiry. Educational Researcher, 32(1), 5-8. http://dx.doi.org/10.3102/0013189X032001005

Drucker, P. (1999). Management challenges for the 21st century. New York: Harper Collins.

Dufour, R. (2004). What is a professional learning community? Educational Leadership, 61(8), 6-11.

Ellsworth, J. B. (2000). Surviving change: A survey of educational change models. Syracuse, NY: ERIC Clearninghouse on Information and Technology.

Ely, D. P. (1990). Conditions that facilitate the implementation of educational technology innovations. Journal on Research on Computing in Education, 23(2), 298-305.

Ely, D. P. (1999). Conditions that facilitate the implementation of educational technology innovations. Educational Technology, 39, 23-27.

Ensminger, D. C., Surry, D. W., Porter, B. E., \& Wright, D. (2004). Factors contributing to the successful implementation of technology innovations. Educational Technology \& Society, 7(3), 61-72.

Fishman, B. J. (2000). How activity fosters CMC tool use in classrooms: Reinventing innovations in local contexts. Journal of Interactive Learning Research, 11, 3-27.

Fullan, M. (2001). The new meaning of educational change ( $3^{\text {rd }}$ ed.). New York, NJ: Teachers College Press.

Fullan, M. (2010). The Six Secrets of Change: What the Best Leaders Do to Help Their Organizations Survive and Thrive. San Francisco: Josey-Bass.

Hall, G. E., \& Hord, S. M. (2001). Implementing change: Patterns, principles, and potholes, Massachusetts: Addison-Wesley Publishing Company.

Hall, G., \& Hord, S. (1987). Change in schools: Facilitating the process. Albany, NY: State University of New York Press.

Hayes, A. F., \& Krippendorff, K. (2007). Answering the Call for a Standard Reliability Measure for Coding Data. Communication Methods and Measures, 1(1), 77-89. http://dx.doi.org/10.1080/19312450709336664

Kaptelinin, V., \& Nardi, B. (2006). Acting with technology: Activity theory and interaction design. Cambridge, MA: MIT press.

Kozma, R. B. (Ed.). (2003). Technology, innovation, and educational change: A global perspective. Washington, DC: ISTE.

Krippendorf, K. (2003). Unitizing. In K. Krippendorf, Content Analysis: An introduction to its methodology (2 $2^{\text {nd }}$ ed.) (pp. 97-110). Thousand Oaks, CA: SAGE Publications.

Laferrière, T. (2005). Les communautés d'apprenants en réseau au bénéfice de l'éducation. Encounters on Education, 6, 5-21.

Laferrière, T., Breuleux, A., \& Inchauspé, P. (2004). L'école éloignée en réseau. Rapport de recherche. Québec: CEFRIO.

Laferrière, T., Hamel, C., Allaire, S., Turcotte, S., Breuleux, A., \& Beaudoin, J., et al. (2011). L'École éloignée en réseau, un modèle. Rapport-synthèse, octobre 2011. CEFRIO.

Lave, J., \& Wenger, E. (1991). Situated learning: Legitimate peripheral participation. Cambridge: Cambridge University Press. http://dx.doi.org/10.1017/CBO9780511815355

Miles, M. B., \& Huberman, A. M. (1999). Qualitative data analysis (3nd ed.). Thousand Oaks, CA: Sage.

Ministère de l'Éducation du Québec [MEQ]. (2001). Le programme de formation de l'école québécoise. Québec : Gouvernement du Québec. 
Morehouse, D. L., \& Stockdill, S. H. (1992). A technology adoption model. Educational Technology, 32(2), 57-58.

Plante, J., \& Beattie, D. (2004). Education, skills and learning - Research papers Connectivity and ICT integration in Canadian elementary and secondary schools: First results from the Information and Communications Technologies in Schools Survey, 2003-2004. Ottawa, Canada: Statistics Canada. Culture, Tourism and the Centre for Education Statistics Division. Retrieved from http://publications.gc.ca/Collection/Statcan/81-595-MIE/81-595-MIE2004017.pdf

Reigeluth, C. (Ed.). (1999). Instructional-design theories and models: A new paradigm of instructional theory, 2. Mahwah: LEA.

Reigeluth, C. M., Carr-Chellman, A. A., Beabout, B., \& Watson, W. (2007). Creating shared visions of the future for K-12 education: A systemic transformation process for a learner-centered paradigm. The Journal of Educational Alternatives, 2(3), 34-66.

Rogers, E. M. (2003). Diffusion of Innovations (4th ed.). New York, NY: The Free Press.

Scardamalia, M. (2002). Collective cognitive responsibility for the advancement of knowledge. In B. Smith (Ed.), Liberal education in a knowledge society (pp. 67-98). Chicago: Open Court.

Scardamalia, M., \& Bereiter, C. (2006). Knowledge building: Theory, pedagogy, and technology. In K. Sawyer (Ed.), Cambridge handbook of the learning sciences (pp. 97-118). New York: Cambridge University Press.

Seidel, R. J., \& Perez, R. S. (1994). An evaluation model for investigating the impact of innovative educational technology. In E. L. Baker, \& H. F. O'Neil, Jr. (Eds.) Technology asssessment in software applications. Hillsdale, NJ: Lawrence Erlbaum Associates.

Spillane, J. P., Reiser, B. J., \& Reimer, T. (2002). Policy implementation and cognition: Reframing and refocusing implementation research. Review of Educational Research, 72(3), 387. http://dx.doi.org/10.3102/00346543072003387

Turcotte, S., \& Hamel, C. (2008). Necessary conditions to implement innovation in remote networked schools: The stakeholders' perceptions. Canadian Journal of Learning and Technology/Revue canadienne de l'apprentissage et de la technologie, 34(1), 91-105.

UNESCO. (2008). ICT Competency Standards for Teachers. Paris: UNESCO.

Zhao, Y., Pugh, K., Sheldon, S., \& Byers, J. L. (2002). Conditions for classroom technology innovations. Teachers College Record, 104(3), 482-515. http://dx.doi.org/10.1111/1467-9620.00170 